\author{
Marquette University \\ e-Publications@Marquette
}

$7-2005$

\title{
Fire Retardancy of Vinyl Ester Nanocomposites: Synergy with Phosphorus-Based Fire Retardants
}

Grace Chigwada

Marquette University

Panchatapa Jash

Marquette University

David D. Jiang

Marquette University

Charles A. Wilkie

Marquette University, charles.wilkie@marquette.edu

Follow this and additional works at: https://epublications.marquette.edu/chem_fac

Part of the Chemistry Commons

\section{Recommended Citation}

Chigwada, Grace; Jash, Panchatapa; Jiang, David D.; and Wilkie, Charles A., "Fire Retardancy of Vinyl Ester Nanocomposites: Synergy with Phosphorus-Based Fire Retardants" (2005). Chemistry Faculty Research and Publications. 129.

https://epublications.marquette.edu/chem_fac/129 
Marquette University

\title{
e-Publications@Marquette
}

\section{Chemistry Faculty Research and Publications/College of Arts and Sciences}

This paper is NOT THE PUBLISHED VERSION; but the author's final, peer-reviewed manuscript. The published version may be accessed by following the link in the citation below.

Polymer Degradation and Stability, Vol. 89, No. 1 (July, 2005). DOI. This article is (C) Elsevier and permission has been granted for this version to appear in e-Publications@Marquette. Elsevier does not grant permission for this article to be further copied/distributed or hosted elsewhere without the express permission from Elsevier.

\section{Fire Retardancy Of Vinyl Ester Nanocomposites: Synergy with Phosphorus-Based Fire Retardants}

\author{
Grace Chigwada \\ Department of Chemistry, Marquette University, Milwaukee, WI \\ Panchatapa Jash \\ Department of Chemistry, Marquette University, Milwaukee, WI \\ David D. Jiang \\ Department of Chemistry, Marquette University, Milwaukee, WI \\ Charles A. Wilkie \\ Department of Chemistry, Marquette University, Milwaukee, WI
}

\begin{abstract}
Vinyl ester (PVE) nanocomposites were prepared using both clay and polyhedral oligosilsesquioxanes (POSS) as the nano-dimensional material. From cone calorimetric data, it was shown that both POSS and clay affect the flammability of the nanocomposites to the same extent. To improve on the flame retardancy, the nanocomposites were combined with phosphorous-containing fire retardants (FRs) and
\end{abstract}


the result compared to the benchmark halogen-containing system. The use of the cone calorimeter to investigate the fire properties of these nanocomposites showed a great reduction in peak heat release rate (PHRR) in the presence of phosphate and slight improvements in average mass loss rate (AMLR) while thermogravimetric analysis showed improvement in char yield in the presence of phosphate. Several different organically modified clays were used and they affected the flammability to different extents. The time that the resin and clay were mixed and the atmosphere in which the reaction was carried out do not have an effect on the flammability and thermal stability of the nanocomposites. The effect of curing temperature on the clay dispersion and flammability was also investigated.

\section{Keywords}

Vinyl esters; Nanocomposites; Fire retardancy; Thermal stability

\section{Introduction}

Vinyl ester resins give high performance composites at low cost and these composites possess superior material properties, compared to most unsaturated polyesters. ${ }^{1}$ Glass fibre reinforced vinyl ester resins are also increasingly used for military and commercial applications due to good toughness, excellent chemical resistance and good mechanical properties. ${ }^{2,3,4,5}$

Vinyl ester resins are mixtures of styrene (ST) and methacrylated epoxy. Styrene has one reactive vinyl group while the vinyl ester monomer has several reactive vinyl end groups that provide cross-linking capacity and branching while styrene provides linear chain extension. The polymerisation proceeds by free radical chain growth. $1,2,3,4,5,6,7$

Earlier work on the cure kinetics of the reaction showed that the temperature at which the curing is conducted and the concentration of the catalyst greatly affect the mechanical properties of the vinyl ester. ${ }^{4}$ It has been shown that low post-curing temperatures promote completion of the cross-linking process while introducing relaxation to the cross-linked network. ${ }^{2}$ Increased cross-link density improves mechanical stability while the cross-link relaxation has the potential to increase ductility (energy absorption during fracture).

Gilman et al. prepared nanocomposites of vinyl esters and showed formation of intercalated composites with $25-39 \%$ reductions in peak heat release rate, PHRR, and equally significant reductions in mass loss rate, $M L R$, and average heat release rate, AHRR, for samples prepared by mixing for a specific time in air. ${ }^{8}$ The effect of curing temperature was investigated by varying the curing and post-curing temperatures.

Nanocomposite formation results in a number of improved properties and, among these, enhanced fire retardancy of the polymers is one of the most important. Reduced flammability is shown by reduction in the peak heat release rate (PHRR) from cone calorimetric measurements. Despite large reductions in PHRR, nanocomposite formation is typically also associated with small reductions in time to ignition $\left(t_{\text {ign }}\right)$, which may not be significant, and no change in the total heat released (THR). This means nanocomposite formation results in the formation of compounds that are easy to ignite and also, like the virgin polymer, everything eventually will burn. The typical nanomaterial is clay, but graphite, singlewall and double-wall carbon nanotubes, double-layered hydroxides and polyhedral oligosilsesquioxanes (POSS), ${ }^{9,10}$ have also been used. 
Polyhedral oligosilsesquioxanes (POSS) are cage-like hybrid molecules of silicon and oxygen. They have chemical composition of $\left(\mathrm{RSiO}_{1.5}\right)$ similar to that of both silica $\left(\mathrm{SiO}_{2}\right)$ and silicone $\left(\mathrm{R}_{2} \mathrm{SiO}\right)$. Each POSS molecule contains non-reactive organic functionalities for solubility and compatibility of the POSS segments with various polymer systems. ${ }^{11}$

In order to prevent complete combustion of the polymers, additives have been used. The additives that are currently used are mainly halogenated, ${ }^{12}$ but also non-halogenated additives have been effective in lowering both the peak heat release rate and the total heat released, however, the time to ignition is not changed compared to the virgin polymer. ${ }^{13,14,15,16}$ The disadvantage of using additives is that very high quantities have to be used and the degradation products of halogenated compounds have environmental concerns associated with them.

In this study synergy between vinyl ester nanocomposite formation and putative phosphorouscontaining fire retardants has been investigated. This was achieved by adding known amounts of conventional phosphorus-containing fire retardants (FRs) during preparation of the nanocomposites. The phosphorous-containing fire retardants were evaluated using a high throughput technique; those that gave the most interesting results were then further evaluated. Both a variety of putative fire retardants and different clays, with various organic modifications, were investigated. The results were compared with the commercially available brominated vinyl ester.

\section{Experimental}

\subsection{Materials}

The organically modified montmorillonite, containing a dimethyl dihydrogenated tallow ammonium cation (hydrogenated tallow is a mixture of $\sim 65 \% \mathrm{C} 18, \sim 30 \% \mathrm{C} 16$ and $\sim 14 \% \mathrm{C} 14$ ) substituted clay, Closite 15A, was supplied by Southern Clay Products, Inc. Three vinyl esters were obtained from Dow Chemical Company; (1) bisphenol-A/novolac epoxy based vinyl ester, a combination of bisphenol-A epoxy based vinyl ester and novolac epoxy based vinyl ester, mass fraction of $67 \%$ in styrene, Derakane 441-400; (2) bisphenol-A-epoxy based vinyl ester, a combination of a nitrile rubber and bisphenol-Aepoxy based vinyl ester, mass fraction of $58 \%$ in styrene, Derakane 8084; and (3) brominated bisphenolA-epoxy based vinyl ester resin, Derakane 1510C-350. The initiator, 2-butanone peroxide, BuPO, was supplied by Aldrich Chemical Company and cobalt naphthenate, CoNp, mass fraction $6 \%$ in mineral spirits, was obtained from OMG Americans, Inc. POSS, in the form of the Vinyl POSS Cage Mixture, was provided by Hybrid Plastics, Inc. Great Lakes Chemical Company, Clariant Corporation, Akzo-Nobel, Monsanto, Solutia, Rhodia and Dover Chemical Cooperation provided the putative phosphorouscontaining fire retardants.

\subsection{Instrumentation}

$\mathrm{X}$-ray diffraction (XRD) measurements were performed using Rigaku powder diffractometer with a $\mathrm{Cu}$ tube source $(\lambda=1.54 \AA)$ at a generator tension of $50 \mathrm{kV}$ and a current of $20 \mathrm{~mA}$; scans were taken from $2 \vartheta=0.1-10$, step size $=0.1$ and scan time per step of $10 \mathrm{~s}$ using the high-resolution mode.

Thermogravimetric analysis, TGA, was performed on a Cahn TG-131 under flowing nitrogen (60 mL/min) at a scan rate of $10^{\circ} \mathrm{C} / \mathrm{min}$ from $20^{\circ} \mathrm{C}-600^{\circ} \mathrm{C}$; all TGA experiments have been performed in triplicate and the reproducibility of temperature is $\pm 3{ }^{\circ} \mathrm{C}$ while amount of nonvolatile residue is reproducible to $\pm 2 \%$. Cone calorimeter measurements at $35 \mathrm{~kW} / \mathrm{m}^{-2}$ were performed using an Atlas Cone 2 according to ASTM E 1354-92; the spark was continuous until the sample ignited. Curing and post-curing of samples 
in pre-formed aluminium foil was used to prepare $20-50 \mathrm{~g}$ samples for cone calorimetry. All samples were run in triplicate and the average value is reported. The results from cone calorimeter are reproducible to $\pm 10 \%$, based on the work of Gilman et al. ${ }^{8}$ Infrared spectroscopy, FTIR, was performed on Matson Galaxy IR spectrometer at $4 \mathrm{~cm}^{-1}$ resolution. Mechanical testing was performed on a Reliance RT/5 (MTS system Corporation, Model \#4501029) computerized system for material testing at a crosshead speed of $0.2 \mathrm{in} / \mathrm{min}$ and $5 \mathrm{kN}$ load cell. Curing and post-curing samples in dogbone-shaped aluminium containers were used to prepare samples for mechanical testing. Bright field transmission electron microscopy (TEM) images of the composites were obtained at $60 \mathrm{kV}$ with a Zeiss $10 \mathrm{c}$ electron microscope. The samples were ultramicrotomed with a diamond knife on a Reichert-Jung Ultra-Cut $E$ microtome at room temperature to give $\sim 70 \mathrm{~nm}$ thick section. The sections were transferred from the knife-edge to 600 hexagonal mesh Cu grids.

\subsection{Identification of potential fire retardants}

For the evaluation of potential fire retardants, a high throughput evaluation was used. The vinyl ester resin was mixed with $6 \%$ Cloisite $15 \mathrm{~A}$ for $3 \mathrm{~h}$, then the mixture was transferred to a $9 \mathrm{~mm}$ test tube to which the putative fire retardant (15\%) was added to make $1.5 \mathrm{~g}$ samples. To this system was added $1.25 \%$ BuPO and the mixture stirred for a few minutes, followed by the addition of $0.3 \%$ CoNp. The samples were cured at room temperature for $12 \mathrm{~h}$ and then post-cured at $80^{\circ} \mathrm{C}$ for $8 \mathrm{~h}$. The samples, in the form of cylinders, were removed from the test tubes and the flammability of the samples was evaluated by placing a flame in contact with the top of the sample for $1 \mathrm{~min}$. The flame was then moved on to the next sample and the time that each sample burned was recorded. Any samples that did not burn at all under the specified conditions were considered to be promising and were evaluated on a larger scale. This procedure was validated by also preparing larger samples of a few phosphoruscontaining fire retardants which burned for longer times and these were found to be ineffective in a cone calorimetric evaluation.

\subsection{Further evaluation of phosphorous-containing fire retardants}

Large, $130 \mathrm{~g}$, samples of vinyl ester nanocomposites containing a putative fire retardant were prepared at room temperature by mixing the resin with $6 \%$ clay and FR using a mechanical stirrer. The initiator, BuPO (1.25\%), was added and mixture stirred for a few minutes. This was then followed by the addition of the catalyst, CoNp (0.3\%), and stirring continued until the catalyst was well distributed in the mixture. The sample was quickly transferred to aluminium dishes, making 30 g samples for cone samples, flat samples for XRD measurements and dogbone-shaped dishes for mechanical properties measurements. The samples were cured at room temperature for $12 \mathrm{~h}$ and post-cured at $80^{\circ} \mathrm{C}$ for $8 \mathrm{~h}$. The effect of mixing time before the initiator was added was investigated by varying the time from a few minutes to several hours and the effect of curing the samples under different environments, air and nitrogen, was also investigated. The amount and identity of the fire retardant and the organically modified clay was varied to ascertain how the thermal stability and flammability of the polymer is affected by the quantity of the fire retardant that was used. 


\section{Results and discussion}

\subsection{I: PVE/phosphate (FR)/clay nanocomposites}

\subsubsection{High throughput evaluation of additives}

A total of 36 putative phosphorous-containing fire retardants were tested using the high throughput technique. Out of all the 36 samples tested, 10 did not burn at all with the non-rubber-containing resin and 12 did not burn with the rubber-containing resin. Of these 3 , namely tricresylphosphate (TCP), resorcinol di-phosphate (RDP) and phosphoryl chloridepolymer/triphenylphosphate did not burn with both resins. A summary of burning times and sample identities is given in Table 1. Tricresylphosphate and resorcinol di-phosphate were selected for further study. The other materials were not further investigated since they caused a large amount of plasticisation.

Table 1. High throughput evaluation of phosphorous-containing materials

\begin{tabular}{|c|c|c|}
\hline Phosphate & Burning time (s) & \\
\hline & No rubber & $\begin{array}{l}\text { Rubber- } \\
\text { containing resin }\end{array}$ \\
\hline Phosphoric acid, methyl, dimethyl ester, dimethylphosphate & 7 & 0 \\
\hline Tributylphosphate & 127 & 125 \\
\hline Tricresylphosphate & 0 & 0 \\
\hline Triphenylphosphate & 0 & 15 \\
\hline Triarylphosphate, Isopropyl acid \& Triarylphosphate & 0 & 9 \\
\hline Tri( $n)$ butylphosphate & 120 & 140 \\
\hline Triarylphosphate, Isopropylated \& Triphenylphosphate & 45 & 0 \\
\hline Tris(2-ethylhexylphosphate) & 132 & 143 \\
\hline Tricresylphosphate & 0 & 0 \\
\hline Bisphenol-A di-phosphate & 5 & 0 \\
\hline Triarylphosphates, Isopropylated, Triarylphosphate & 10 & 45 \\
\hline Trixylylphosphate & 0 & 45 \\
\hline 2-Ethylhexyldiphenyl phosphate & 43 & 18 \\
\hline Alkyl-aryl phosphate & 160 & 148 \\
\hline Oligomeric phosphates & 0 & 0 \\
\hline Phosphoryl chloridepolymer/Triphenylphosphate & 0 & 0 \\
\hline Isodecyldiphenylphosphate & 177 & 144 \\
\hline $\begin{array}{l}\text { 2-Ethyldiphenyl phosphate containing di-2- } \\
\text { ethylhexylphosphate }\end{array}$ & 124 & 145 \\
\hline Phosphoric acid, $\mathrm{C}_{12,14,16}$ alkyldiphenyl ester & 143 & 166 \\
\hline Phosphoric acid, Tris (2-ethylhexyl) ester & 147 & 95 \\
\hline Phosphorous acid, Trisoctyl ester & 107 & 110 \\
\hline Phosphate (phosphoric acid, Triphenyl ester) & 128 & 100 \\
\hline Phosphoric acid, (2-chloroethyl)-bis-(2-chloroethyl) ester & 13 & 0 \\
\hline (Trismonochloropropyl)phosphate & 46 & 5 \\
\hline Propanol-1,3-dichlorophosphate & 55 & 0 \\
\hline Alkyl-aryl phosphate & 30 & 8 \\
\hline Phosphoric acid, methyl dimethyl ester & 0 & 20 \\
\hline 1,2-Ethanediaminephosphate & 3 & 0 \\
\hline Trisnonylphenol phosphite triisopropanolamine & 0 & 240 \\
\hline
\end{tabular}




\begin{tabular}{|l|l|l|}
\hline Triphenylphosphite & 111 & 90 \\
\hline Trilaurylphosphite & 0 & 200 \\
\hline Alkyl(C12-C15)bisphenol-A phosphate & 170 & 187 \\
\hline
\end{tabular}

\subsubsection{X-ray diffraction characterization of nanocomposites}

Previous work on vinyl ester resins by Gilman et al. showed that vinyl ester nanocomposites mixed for $10 \mathrm{~min}$ in air results in the formation of intercalated structures. ${ }^{8}$ The XRD traces for the nanocomposites prepared under different conditions and in the presence and absence of phosphate are shown in Fig. 1 , Fig. 2, Fig. 3. Fig. 1 shows that intercalated nanocomposites with a $d$-spacing of $3.84 \mathrm{~nm}, 2 \vartheta=2.3^{\circ}$, were formed, regardless of the time of mixing between a few minutes and several hours; a summary of the $2 \vartheta$ values for the different mixing times is provided in Table 2. Because results from cone calorimetry seemed to show better performance at a $3 \mathrm{~h}$ mixing time, this was established as the time of mixing for this study. Fig. 2 shows that the same $d$-spacing is obtained for mixing in both air and nitrogen. Once nanodispersion was established with vinyl ester nanocomposites, the effect of adding phosphorous compound was investigated. From Fig. 3, the position of the peak is not affected by the type or amount of phosphate, but peak intensity is lowered as the amount of phosphate is increased; the presence of phosphate does not affect the nanodispersion of the clay in the polymer.

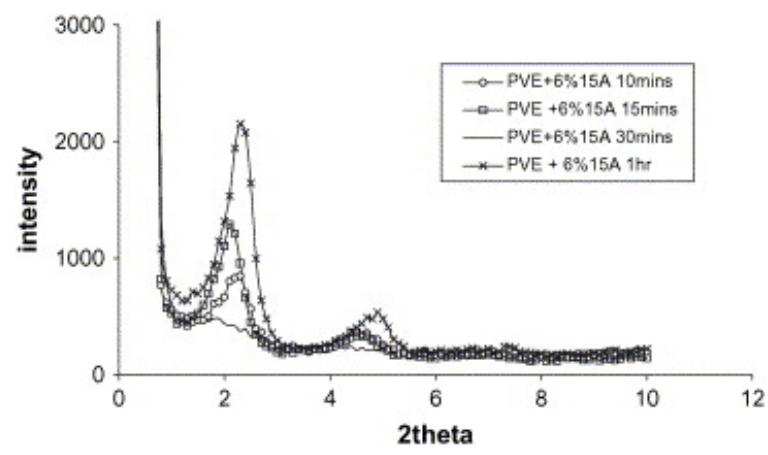

Fig. 1. XRD trace for Derakane 441-400(PVE) with Cloisite 15A at different mixing times.

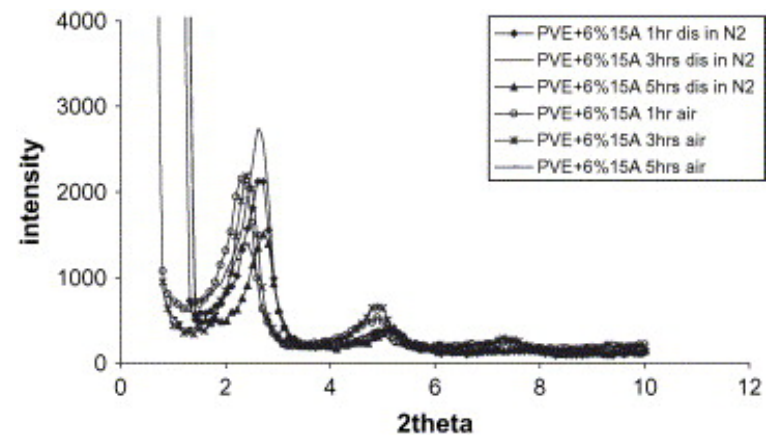

Fig. 2. XRD traces for PVE $+6 \%$ Cloisite $15 \mathrm{~A}$ in air and nitrogen at different mixing times. 


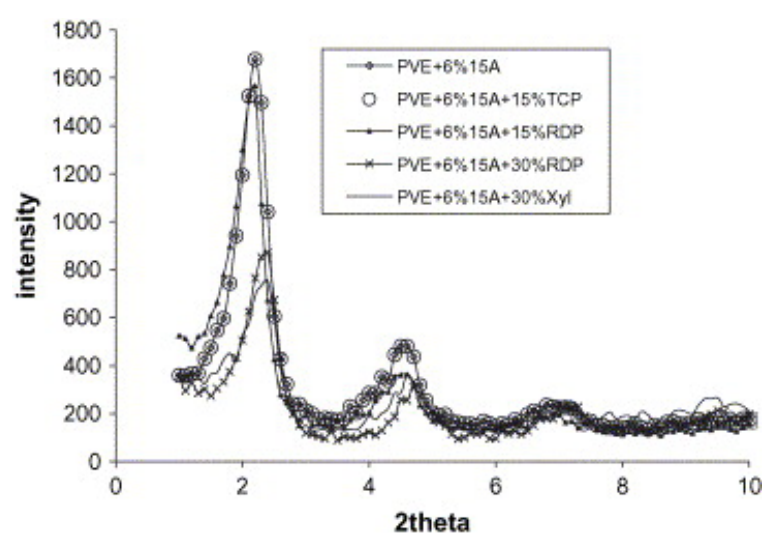

Fig. 3. XRD traces for PVE + Cloisite $15 A+$ phosphate.

Table 2. XRD data for various mixing times

\begin{tabular}{|l|l|l|}
\hline PVE $+\mathbf{6 \%} \mathbf{1 5 A}$ after mixing for & $\mathbf{2 \vartheta}$ & $\boldsymbol{d}$-Spacing $\mathbf{( n m})$ \\
\hline $10 \mathrm{~min}$ & 2.35 & 3.8 \\
\hline $15 \mathrm{~min}$ & 2.15 & 4.1 \\
\hline $30 \mathrm{~min}$ & 1.9 & 4.7 \\
\hline $1 \mathrm{~h}$ & 2.35 & 3.8 \\
\hline $2 \mathrm{~h}$ & 2.25 & 3.9 \\
\hline $3 \mathrm{~h}$ & 2.35 & 3.8 \\
\hline $4 \mathrm{~h}$ & 2.1 & 4.2 \\
\hline $5 \mathrm{~h}$ & 2.4 & 3.7 \\
\hline
\end{tabular}

Fig. 4 shows the XRD result for the nanocomposites formed using COPS and DPVPP clays. COPS clay contains an oligomeric styryl unit in the cation and has been shown to give exfoliated systems in a variety of polymers, ${ }^{17,18}$ while DPVPP clay ${ }^{14}$ contains an oligomeric unit of styrene and diphenyl vinylphenylphosphate and permits the delivery of phosphorus to the polymer through the clay cation. With DPVPP and COPS clays no peaks were observed from XRD, suggesting that the organic modification on the clay is quite important in determining the type of nanocomposite that may be formed. This is further shown by results when Magadiite, Mgd, modified clay ${ }^{19}$ and VB16-modified $\mathrm{MMT}^{20}$ clays were used, in both cases peaks were observed, however, their position and breadth is different from that obtained when Cloisite 15A was used. Cloisite 15A, Mgd and VB16-modified MMT clays give intercalated nanocomposites and the others clays form either exfoliated nanocomposites or disordered systems.

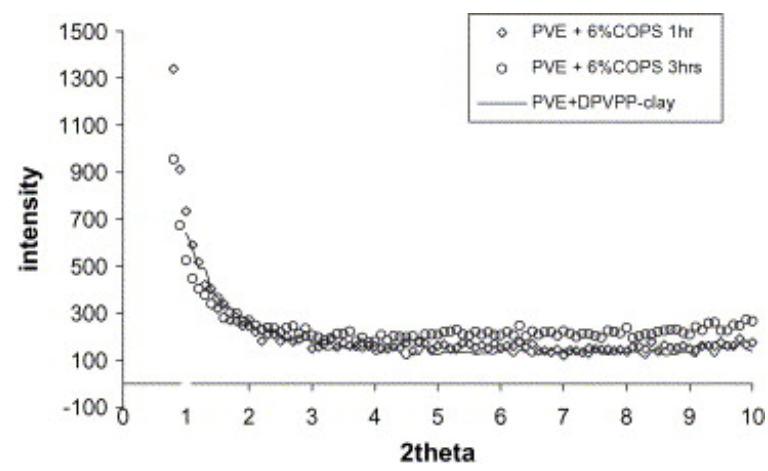

Fig. 4. XRD traces for PVE + clays. 
Fig. 5 shows the XRD traces for PVE-clay nanocomposites in the presence of brominated-antimony fire retardants. Both in the presence and absence of the fire retardant, the formation of intercalated nanocomposites with a $d$-spacing of about $4.0 \mathrm{~nm}$ was observed; the presence of the additive does not affect the nature of the nanocomposite formed.

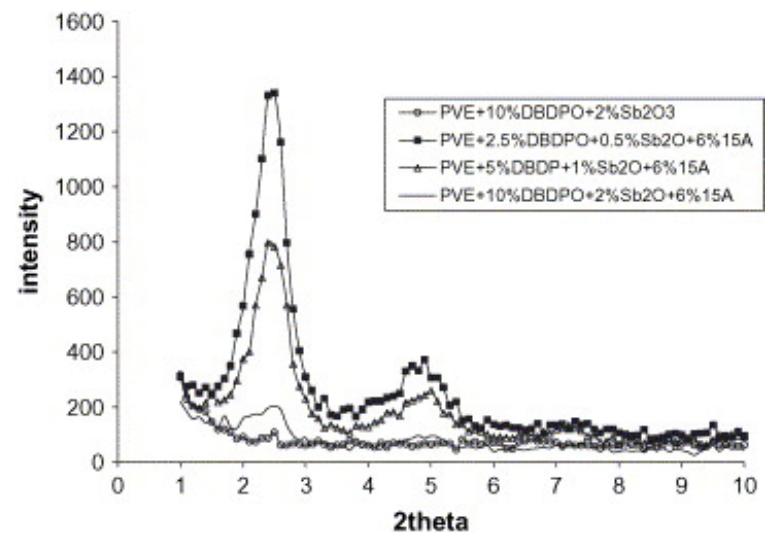

Fig. 5. XRD traces for PVE nanocomposite in the presence of decabromodiphenyl oxide and antimony oxide.

\subsubsection{Transmission electron microscopy of clay nanocomposites}

The transmission electron microscopy, TEM, image at low magnification is used to determine if the clay is well-dispersed in the polymer while the high magnification images are used to determine the nature of the nanocomposites, intercalated or exfoliated. Fig. 6, Fig. 7, Fig. 8 show the TEM images for the PVE nanocomposites at different mixing times; there does not appear to be any significant difference due to the time of mixing. The low magnification images, shown on the right in all the figures, show the presence of clay tactoids, suggesting some immiscibility between the polymer and the organically modified clay, an indication that the degree of nanodispersion may be lower than what has been obtained with other polymers. The high magnification images indicate that polymer has inserted between the clay layers and that intercalation has occurred. Fig. 9 shows the TEM images in the presence of a phosphate and the nanodispersion appears to be much better in this case.
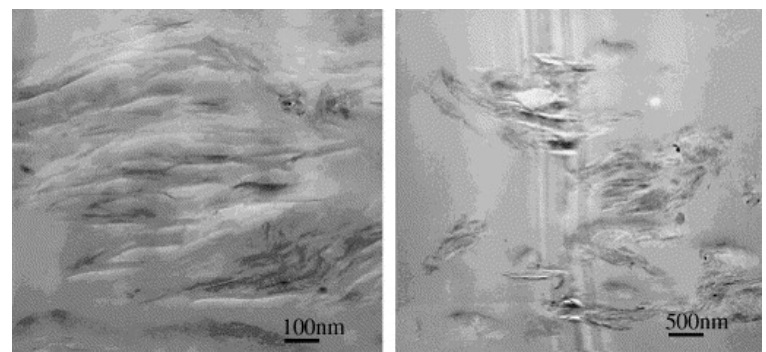

Fig. 6. TEM images at high (left) and low (right) magnification for PVE nanocomposites at 15 min mixing time. 

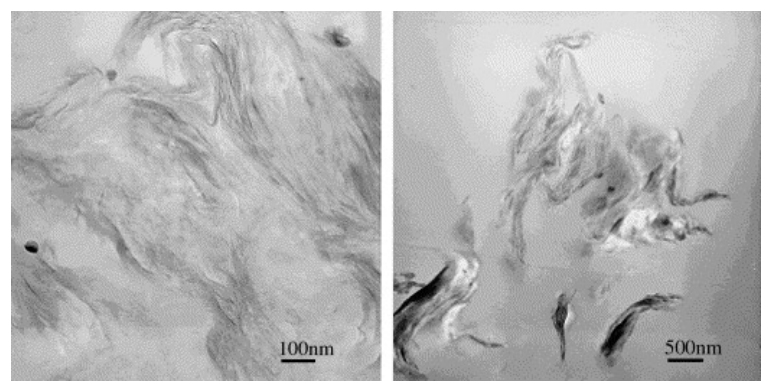

Fig. 7. TEM images at high (left) and low (right) magnification for PVE nanocomposites at $3 \mathrm{~h}$ mixing time.
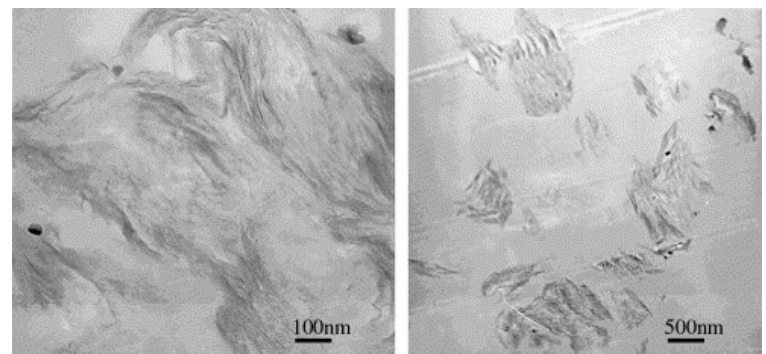

Fig. 8. TEM images at high (left) and low (right) magnification for PVE nanocomposites at $5 \mathrm{~h}$ mixing time.
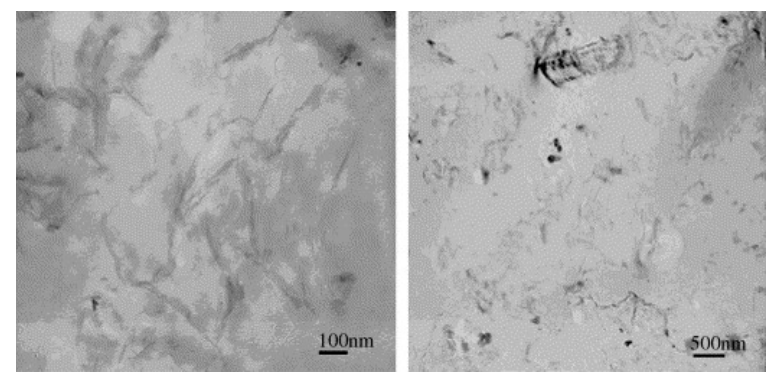

Fig. 9. TEM images at high (left) and low (right) magnification for PVE nanocomposites $+30 \%$ phosphorus-containing fire retardant at $3 \mathrm{~h}$ mixing time.

Before curing of the resin, one could not see the presence of clay by visual examination, indicating that dispersion is good on the microscale. It may be speculated that the cross-linking process causes agglomeration of the clay, leading to the poorer dispersion. In an attempt to improve the clay dispersion, the curing temperature was varied and Fig. 7, Fig. 10, Fig. 11 show how the dispersion varied with curing temperature. It is evident from the low magnification images that the curing temperature affects the dispersion of the clay, curing at low temperature apparently gives the best nanodispersion.
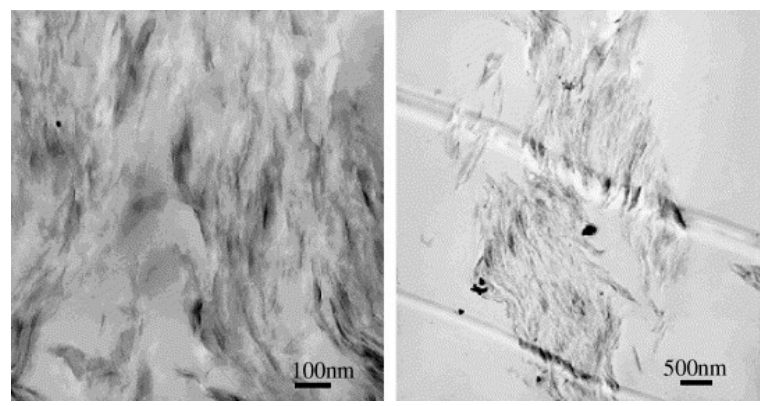

Fig. 10. TEM images at high (left) and low (right) magnification for PVE nanocomposites cured at $0{ }^{\circ} \mathrm{C}$. 

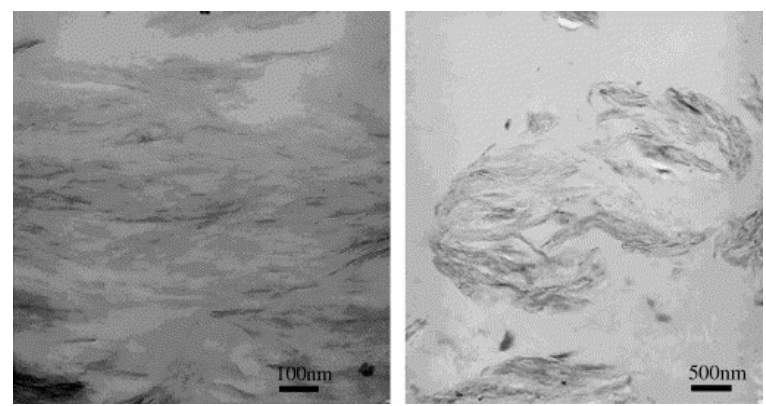

Fig. 11. TEM images at high (right) and low (left) magnification for PVE nanocomposites cured at $90{ }^{\circ} \mathrm{C}$.

\subsubsection{Thermogravimetric analysis}

Epoxy vinyl ester resins are known to form nanocomposites with high cross-link density and generally have high thermal stability. ${ }^{2}$ As can be seen from thermogravimetric analysis (TGA), Fig. 12, Fig. 13, Fig. 14, Fig. 15 and Table 3, the formation of a nanocomposite or nanocomposite and a fire retardant does not change the onset degradation temperature of the polymer. In some cases, e.g., polystyrene, the onset temperature increases by about $50{ }^{\circ} \mathrm{C}$ while for others, e.g., PMMA, there is no change in the onset temperature. ${ }^{21} \mathrm{It}$ is perhaps notable that the char yield of nanocomposite in the presence of phosphate is higher than that of pure epoxy vinyl ester, suggesting some condensed phase role for the phosphate. From Table 3 the char yield is significantly higher when both phosphate and clay are present for most clays, VB16-modified MMT is the exception, again showing the variability of the different clays.

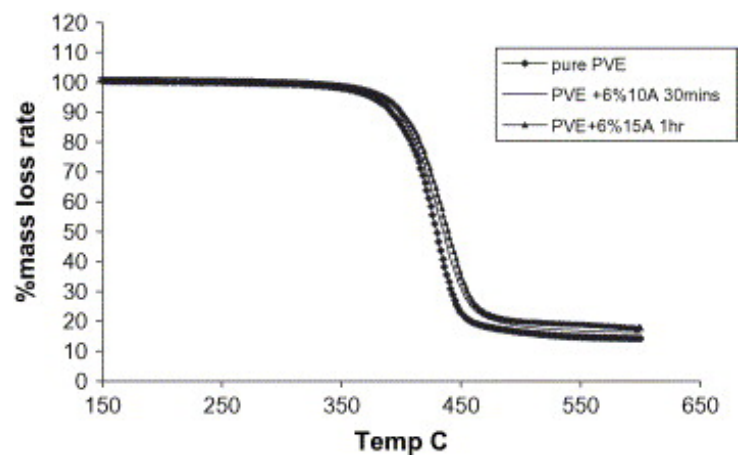

Fig. 12. TGA analysis for PVE + Cloisite $15 \mathrm{~A}$ at different mixing times.

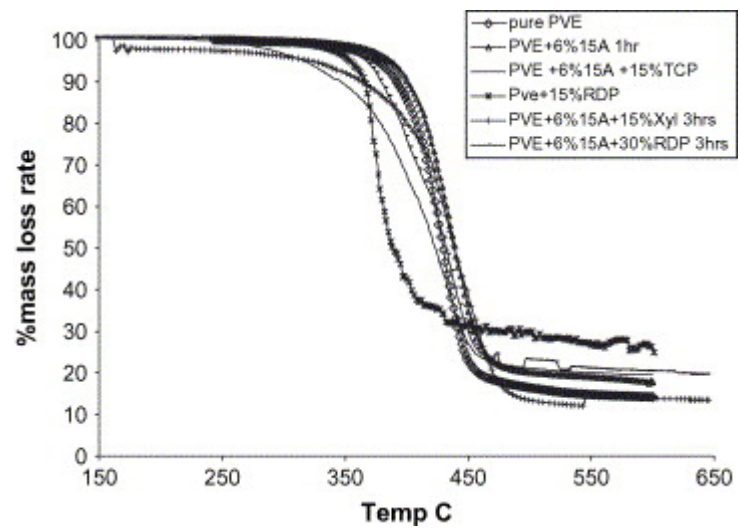

Fig. 13. TGA analysis for PVE + Cloisite $15 A+$ phosphate at different mixing times. 


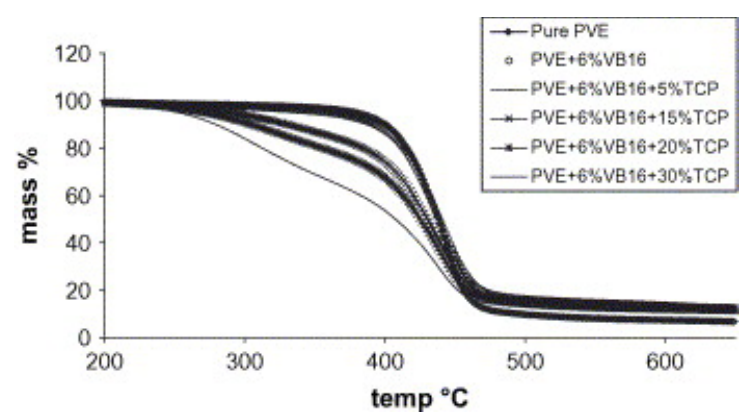

Fig. 14. TGA curves for PVE samples containing VB16-modified MMT.

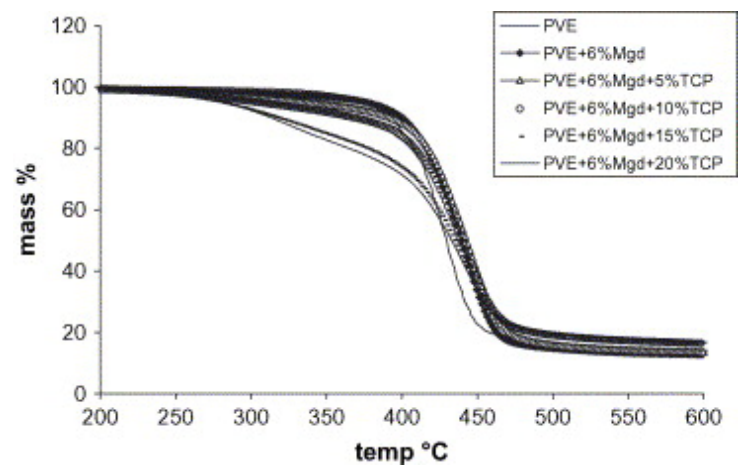

Fig. 15. TGA curves for PVE samples containing Magadiite clay.

Table 3. TGA data for PVE samples containing MMT-15A, MMT-VB16 and Magadiite, Mgd, clays

\begin{tabular}{|c|c|c|c|}
\hline Sample & $T_{10}$ & $T_{50}$ & $\%$ Char at $600{ }^{\circ} \mathrm{C}$ \\
\hline Pure PVE & 400 & 438 & 7 \\
\hline PVE $+6 \% 15 \mathrm{~A}, 30 \mathrm{~min}$ & 396 & 435 & 17 \\
\hline PVE + 6\% 15A, $1 \mathrm{~h}$ & 391 & 433 & 13 \\
\hline PVE + 6\% 15A + 15\% TCP, $3 \mathrm{~h}$ & 345 & 423 & 20 \\
\hline PVE + 15\% RDP, 30 min & 364 & 386 & 14 \\
\hline PVE $+6 \% 15 A+5 \%$ RDP, $3 \mathrm{~h}$ & 409 & 461 & 36 \\
\hline PVE + 6\% 15A + 30\% RDP, $3 \mathrm{~h}$ & 378 & 430 & 20 \\
\hline PVE $+6 \%$ COPS, $1 \mathrm{~h}$ & 387 & 432 & 8 \\
\hline PVE + 6\% VB16 & 392 & 438 & 14 \\
\hline $\mathrm{PVE}+6 \%$ VB16 + 5\% TCP & 397 & 438 & 10 \\
\hline PVE + 6\% VB16 + 15\% TCP & 330 & 430 & 13 \\
\hline PVE + 6\% VB16 + 20\% TCP & 303 & 425 & 12 \\
\hline PVE + 6\% VB16 + 30\% TCP & 285 & 410 & 12 \\
\hline PVE + 6\% Mgd & 397 & 439 & 13 \\
\hline PVE + 6\% Mgd + 5\% TCP & 392 & 443 & 14 \\
\hline PVE + 6\% Mgd + 10\% TCP & 367 & 440 & 16 \\
\hline PVE + 6\% Mgd + 15\% TCP & 313 & 434 & 17 \\
\hline PVE + 6\% Mgd + 20\% TCP & 307 & 433 & 17 \\
\hline
\end{tabular}

The char yield in the presence of clay and phosphate shows synergy between nanocomposite formation and the presence of a phosphorous-containing-compound. It is also important to note that increasing 
the amount of phosphorous-containing compound does not affect the thermal stability of the vinyl ester.

For the PVE-POSS nanocomposites there was not much change in the TGA curves, however, there is a significant amount of char produced in the presence of both phosphate and POSS, as shown in Table 4 and Fig. 16. Table 5 and Fig. 17 show the TGA results on the thermal stability of $\mathrm{PVE} / \mathrm{Sb}_{2} \mathrm{O}_{3}+\mathrm{DBDPO} /$ clay nanocomposites; there was no improvement in the onset temperature of the degradation, $T_{10}$, or the mid-point temperature of degradation, $T_{50}$. With lower amounts of additive, the thermal stability appears to be lowered; a higher char yield was obtained in the presence of a fire retardant, compared to the virgin polymer.

Table 4. TGA data for PVE-POSS nanocomposites

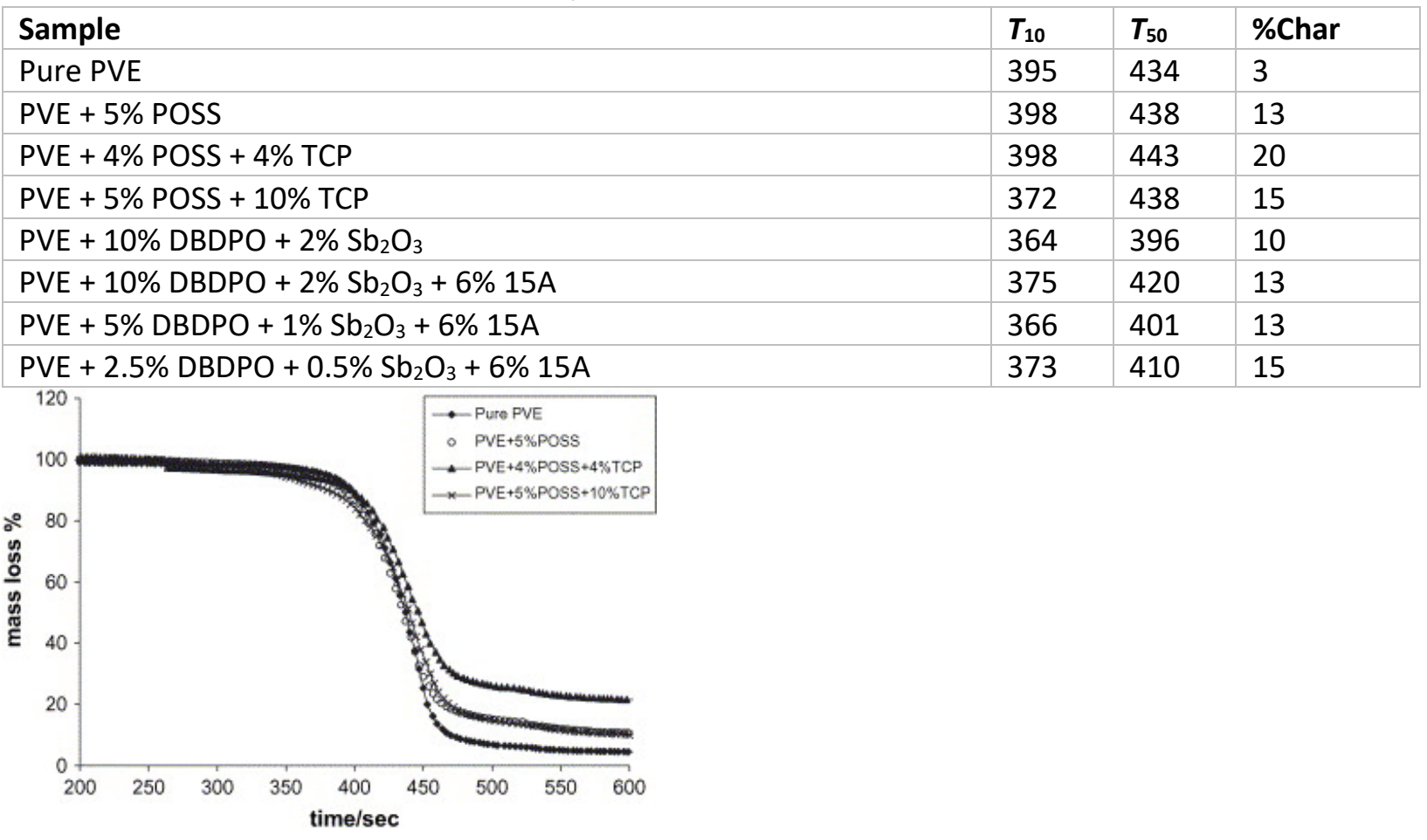

Fig. 16. TGA curves for PVE-POSS systems.

Table 5. Cone data for PVE-clay nanocomposites and nanocomposites + fire retardants

\begin{tabular}{|c|c|c|c|c|c|c|}
\hline Sample & $t_{\text {ign }}(s)$ & $\begin{array}{l}\text { PHRR }\left(\mathrm{kW} / \mathrm{m}^{2}\right) \\
\text { (\%reduction) }\end{array}$ & $t_{\mathrm{PHRR}}(\mathrm{s})$ & $\begin{array}{l}\text { THR } \\
\left(\mathrm{MJ} / \mathrm{m}^{2}\right)\end{array}$ & $\begin{array}{l}\text { AMLR } \\
\left(\mathrm{g} / \mathrm{stm}^{2}\right)\end{array}$ & $\begin{array}{l}\text { ASEA } \\
\left(\mathrm{m}^{2} / \mathrm{kg}\right)\end{array}$ \\
\hline Pure PVE & 82 & 1197 & 106 & 80 & 27 & 1015 \\
\hline $\begin{array}{l}\text { PVE + 6\% 15A, } \\
10 \text { min }\end{array}$ & 45 & $816(32)$ & 90 & 75 & 17 & 1018 \\
\hline
\end{tabular}




\begin{tabular}{|c|c|c|c|c|c|c|}
\hline $\begin{array}{l}\text { PVE + 6\% 15A, } \\
15 \text { min }\end{array}$ & 63 & $828(31)$ & 97 & 75 & 16 & 1023 \\
\hline $\begin{array}{l}\mathrm{PVE}+6 \% 15 \mathrm{~A}, \\
30 \mathrm{~min}\end{array}$ & 62 & $852(29)$ & 113 & 77 & 17 & 1025 \\
\hline PVE $+6 \% 15 \mathrm{~A}, 1 \mathrm{~h}$ & 60 & $878(27)$ & 116 & 78 & 15 & 1103 \\
\hline PVE $+6 \% 15 \mathrm{~A}, 2 \mathrm{~h}$ & 46 & $881(26)$ & 98 & 78 & 21 & 1140 \\
\hline PVE $+6 \% 15 \mathrm{~A}, 3 \mathrm{~h}$ & 53 & $823(31)$ & 83 & 74 & 16 & 1033 \\
\hline PVE $+6 \% 15 \mathrm{~A}, 4 \mathrm{~h}$ & 48 & $875(27)$ & 65 & 73 & 16 & 1137 \\
\hline PVE $+6 \% 15 \mathrm{~A}, 5 \mathrm{~h}$ & 45 & $963(20)$ & 68 & 79 & 16 & 1165 \\
\hline $\begin{array}{l}P V E+6 \% 15 A-N_{2} \\
0.5 h\end{array}$ & 63 & $909(24)$ & 102 & 91 & 18 & 1100 \\
\hline $\begin{array}{l}P V E+6 \% 15 A-N_{2} \\
1 h\end{array}$ & 75 & $787(34)$ & 108 & 89 & 17 & 1029 \\
\hline $\begin{array}{l}P V E+6 \% 15 A-N_{2} \\
3 h\end{array}$ & 56 & $952(20)$ & 85 & 90 & 18 & 1041 \\
\hline $\begin{array}{l}P V E+6 \% 15 A-N_{2} \\
5 h\end{array}$ & 71 & 845 (29) & 109 & 86 & 17 & 1047 \\
\hline $\begin{array}{l}\text { PVE }+1.5 \% \text { COPS, } \\
0.5 \mathrm{~h}\end{array}$ & 73 & $1002(16)$ & 103 & 89 & 26 & 1238 \\
\hline PVE $+1.5 \%$ COPS, $1 \mathrm{~h}$ & 61 & $1074(10)$ & 114 & 86 & 21 & 985 \\
\hline PVE $+1.5 \%$ COPS, $3 \mathrm{~h}$ & 65 & $912(24)$ & 138 & 81 & 20 & 921 \\
\hline PVE $+6 \%$ COPS, $1 \mathrm{~h}$ & 65 & $841(28)$ & 108 & 83 & 12 & 908 \\
\hline PVE $+6 \%$ COPS, $3 \mathrm{~h}$ & 67 & $979(18)$ & 107 & 85 & 20 & 931 \\
\hline
\end{tabular}

$t_{\text {ign }}$, Time to ignition; PHRR, peak heat release rate; $t_{\mathrm{PHRR}}$, time to PHRR; THR, total heat released; AMLR, average mass loss rate; ASEA, average specific extinction area (smoke).

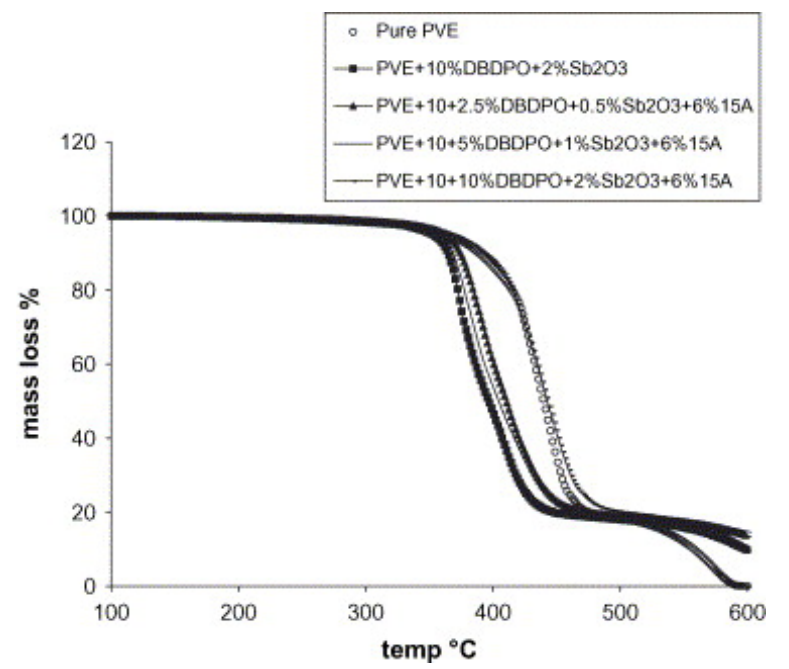

Fig. 17. TGA curves for the PVE/clay/DBDPO/ $\mathrm{Sb}_{2} \mathrm{O}_{3}$ system.

\subsubsection{Cone calorimetric evaluation of phosphate containing nanocomposites}

Cone calorimetry was used to evaluate the fire properties of the system. Various parameters are obtained from cone measurements, including the time to ignition $\left(t_{\text {ign }}\right)$, peak heat release rate (PHRR), time to peak heat release rate, $t_{\mathrm{PHRR}}$, total heat released (THR), average mass loss rate (AMLR) and average specific extinction area (ASEA), a measure of smoke. Most of the work that has been performed 
on nanocomposites has shown a decrease in the time to ignition, decreased PHRR and no change in total heat released compared to the virgin polymer. This would mean nanocomposites are easier to ignite and thus have higher flammability, but produce a smaller fire due to decreased PHRR, but, at the same time, everything ultimately burns, since the total heat produced is not changed.

Table 5 gives a summary of the results obtained for the nanocomposites with different mixing times and also shows the results obtained by mixing in air and in nitrogen using Cloisite 15A and COPS clay. From this table it is clear that the time to ignition is lowered, as expected, and the PHRR is almost the same for different mixing times, but lower than the virgin polymer, and the THR and ASEA are not affected by the time of mixing. The data in nitrogen at various mixing times are also almost constant and the difference between data in air and in nitrogen is within the experimental error for the cone calorimeter and the two organically modified clays give similar cone calorimetric results. This leads to the conclusion that the conditions under which the nanocomposites are formed do not affect the flammability properties of the nanocomposites.

The goal is to reduce the flammability of the vinyl ester through the combination of nanocomposite formation and putative phosphorous-containing fire retardants. Table 6 and Fig. 18, Fig. 19 make it clear that as the amount of phosphate was increased, the time to ignition was not improved; the presence of phosphorous does not affect the time to ignition. However, it is interesting to note that the mass loss rate, peak heat release rate and the total heat released decreased, showing that a significant improvement in the fire retardancy can be achieved through nanocomposite formation in the presence of phosphorus-containing fire retardants. The decrease in the total heat released is an indication that not all of the polymer burns, apparently the presence of the phosphate helps prevent the total loss of the polymer. From the data in Table 6 on pure RDP and TCP, one can calculate that at $30 \%$ phosphate loading, the total heat released would be in the range of $72-82 \mathrm{MJ} / \mathrm{m}^{2}$. Since the experimental value is about $38 \mathrm{MJ} / \mathrm{m}^{2}$, this is a clear indication of the synergistic action between nanocomposite formation and the presence of the phosphate. When compared to the nanocomposite alone, there is not much change in the mass loss rate in the presence of phosphates up to $30 \%$ phosphate loading, but a great decrease is observed when compared to the virgin polymer. The greatest reduction in PHRR (75\%) occurs at $30 \%$ TCP and there is no further decrease beyond this level.

Table 6. Cone calorimetric data for PVE $+6 \% 15 \mathrm{~A}+$ phosphate

\begin{tabular}{|c|c|c|c|c|c|c|}
\hline Sample & $t_{\text {ign }}(s)$ & $\begin{array}{l}\text { PHRR }\left(\mathrm{kW} / \mathrm{m}^{2}\right)(\% \\
\text { reduction) }\end{array}$ & $t_{\mathrm{PHRR}}(\mathrm{s})$ & $\begin{array}{l}\text { THR } \\
\left(\mathrm{MJ} / \mathrm{m}^{2}\right)\end{array}$ & $\begin{array}{l}\text { AMLR } \\
\left(\mathrm{g} / \mathrm{stm}^{2}\right)\end{array}$ & $\begin{array}{l}\text { ASEA } \\
\left(\mathrm{m}^{2} / \mathrm{kg}\right)\end{array}$ \\
\hline Pure PVE & 82 & 1197 & 106 & 80 & 27 & 1015 \\
\hline $100 \%$ TCP & 25 & 663 & 132 & 51 & 29 & 1808 \\
\hline $100 \%$ RDP & 96 & 415 & 260 & 55 & 17 & 1641 \\
\hline $\begin{array}{l}P V E+6 \% 15 A+5 \% \\
R D P, 3 h\end{array}$ & 68 & $856(32)$ & 93 & 69 & 17 & 931 \\
\hline $\begin{array}{l}\text { PVE + 6\% 15A + 10\% } \\
\text { RDP, } 3 \mathrm{~h}\end{array}$ & 74 & $643(46)$ & 106 & 58 & 16 & 1003 \\
\hline $\begin{array}{l}\text { PVE + 6\% 15A + 15\% } \\
\text { RDP, } 30 \text { min }\end{array}$ & 53 & $812(32)$ & 82 & 58 & 20 & 1517 \\
\hline $\begin{array}{l}\text { PVE + 6\% 15A + 15\% } \\
\text { RDP, } 3 \text { h }\end{array}$ & 56 & $512(57)$ & 91 & 51 & 21 & 1044 \\
\hline PVE $+30 \%$ RDP, $30 \mathrm{~m}$ & 48 & $467(61)$ & 49 & 19 & 14 & 1217 \\
\hline
\end{tabular}




\begin{tabular}{|c|c|c|c|c|c|c|}
\hline PVE $+30 \%$ RDP, $3 \mathrm{~h}$ & 86 & $633(47)$ & 87 & 48 & 16 & 1295 \\
\hline $\begin{array}{l}P V E+6 \% 15 A+30 \% \\
\text { RDP }, 30 \mathrm{~min}\end{array}$ & 51 & $617(48)$ & 91 & 46 & 16 & 1328 \\
\hline $\begin{array}{l}\text { PVE + 6\% 15A + 30\% } \\
\text { RDP, } 3 \text { h }\end{array}$ & 81 & $535(55)$ & 110 & 47 & 16 & 1238 \\
\hline $\begin{array}{l}\text { PVE + 6\% 15A + 15\% } \\
\text { TCP, } 3 \mathrm{~h}\end{array}$ & 44 & $670(44)$ & 118 & 47 & 21 & 976 \\
\hline $\begin{array}{l}\mathrm{PVE}+6 \% 15 \mathrm{~A}+30 \% \\
\mathrm{TCP}, 3 \mathrm{~h}\end{array}$ & 29 & $299(75)$ & 105 & 38 & 13 & 1350 \\
\hline $\begin{array}{l}\text { PVE + 6\% 15A + 40\% } \\
\text { TCP, } 3 \mathrm{~h}\end{array}$ & 38 & $397(67)$ & 93 & 35 & 15 & 1721 \\
\hline Brominated PVE & 76 & $460(62)$ & 116 & 38 & 1499 & 19 \\
\hline
\end{tabular}

$t_{\text {ign, }}$ Time to ignition; PHRR, peak heat release rate; $t_{\text {PHRR }}$, time to PHRR; THR, total heat released; AMLR, average mass loss rate; ASEA, average specific extinction area (smoke).

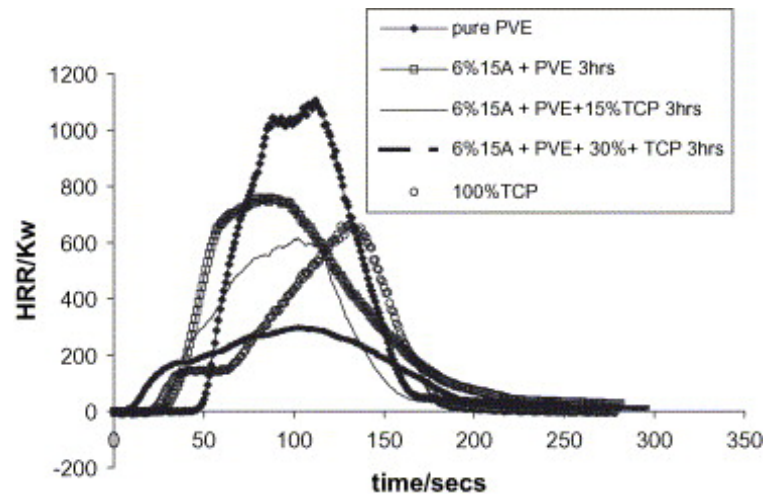

Fig. 18. Heat release curves for PVE + Cloisite $15 \mathrm{~A}+\mathrm{TCP}$ at $3 \mathrm{~h}$ mixing time.

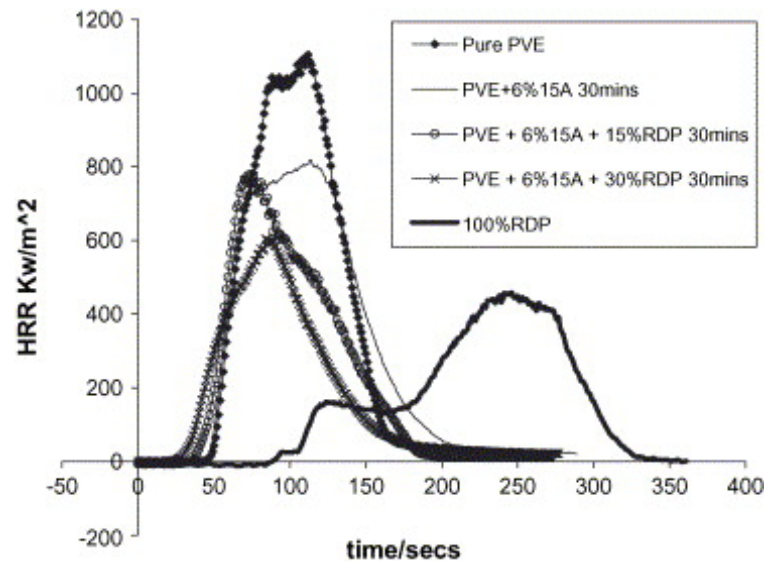

Fig. 19. Heat release curves for PVE + Cloisite $15 A+R D P$ at 30 min mixing time.

The maximum reduction in PHRR is achieved at 15\% for RDP with no change at higher levels but 30\% TCP is required for maximum effect showing that different phosphates affect flammability to different extents and the quantity of phosphate added can be varied to suit the use of the polymer. The difference in effectiveness of TCP and RDP might be due to the difference in the amount of phosphorous. RDP contains more phosphorous (10\%) than TCP (8\% P). 
The brominated vinyl ester resin has a PHHR of $460 \mathrm{~kW} / \mathrm{m}^{2}$ while $30 \%$ TCP and $40 \%$ TCP with $6 \%$ clay gave PHRR of $299 \mathrm{~kW} / \mathrm{m}^{2}$ and $397 \mathrm{~kW} / \mathrm{m}^{2}$, respectively. One may substitute the halogenated compounds with the more environmentally friendly phosphorous-containing compounds and get comparable flammability. However, as discussed below this is achieved with a sacrifice in the mechanical properties and might not be acceptable in some instances.

Table 7 and Fig. 20, Fig. 21, Fig. 22 show data obtained with other clays, both different organic modifiers and different clays. From this data it is clear that clay alone does not give as good an improvement in fire retardancy compared to the nanocomposites in the presence of phosphate additives. Even with DPVPP clay which contains phosphorus on the clay cation and has shown some efficacy with polytstyrene [14], the improvement in flame retardancy is the same as that observed with unfunctionalized organically modified clays.

Table 7. Cone calorimetric data for PVE with different clays and TCP

\begin{tabular}{|c|c|c|c|c|c|c|}
\hline Sample & $t_{\text {ign }}(s)$ & $\begin{array}{l}\text { PHRR }\left(\mathrm{kW} / \mathrm{m}^{2}\right)(\% \\
\text { reduction) }\end{array}$ & $t_{\mathrm{PHRR}}(\mathrm{s})$ & $\begin{array}{l}\text { THR } \\
\left(\mathrm{MJ} / \mathrm{m}^{2}\right)\end{array}$ & $\begin{array}{l}\text { AMLR } \\
\left(\mathrm{g} / \mathrm{stm}^{2}\right)\end{array}$ & $\begin{array}{l}\text { ASEA } \\
\left(\mathrm{m}^{2} / \mathrm{kg}\right)\end{array}$ \\
\hline Pure PVE & 82 & 1197 & 106 & 80 & 27 & 1015 \\
\hline $100 \%$ TCP & 25 & 663 & 132 & 51 & 29 & 1808 \\
\hline $100 \%$ RDP & 96 & 415 & 260 & 55 & 17 & 1641 \\
\hline PVE + 6\% 15A & 53 & $823(31)$ & 83 & 74 & 16 & 1033 \\
\hline $\begin{array}{l}\text { PVE }+6 \% \\
15 A+15 \% \text { TCP }\end{array}$ & 59 & $604(50)$ & 121 & 58 & 17 & 1049 \\
\hline $\begin{array}{l}\text { PVE }+6 \% \\
15 A+30 \% \text { TCP }\end{array}$ & 29 & $299(75)$ & 105 & 38 & 13 & 1350 \\
\hline $\mathrm{PVE}+6 \%$ VB16 & 71 & $822(31)$ & 103 & 62 & 17 & 1084 \\
\hline $\begin{array}{l}\text { PVE }+6 \% \\
\text { VB16 }+5 \% \text { TCP }\end{array}$ & 65 & $756(37)$ & 82 & 70 & 15 & 1082 \\
\hline $\begin{array}{l}\text { PVE }+6 \% \\
\text { VB16 }+15 \% \text { TCP }\end{array}$ & 42 & $546(54)$ & 96 & 56 & 17 & 1306 \\
\hline $\begin{array}{l}\text { PVE }+6 \% \\
\text { VB16 }+20 \% \text { TCP }\end{array}$ & 37 & $479(60)$ & 85 & 53 & 16 & 1694 \\
\hline $\begin{array}{l}\text { PVE }+6 \% \\
\text { VB16 }+30 \% \text { TCP }\end{array}$ & 44 & $399(67)$ & 81 & 41 & 14 & 1627 \\
\hline $\mathrm{PVE}+6 \% \mathrm{Mgd}$ & 69 & $1032(14)$ & 111 & 75 & 20 & 941 \\
\hline $\begin{array}{l}\mathrm{PVE}+6 \% \mathrm{Mgd}+5 \% \\
\mathrm{TCP}\end{array}$ & 66 & $816(32)$ & 110 & 68 & 19 & 1157 \\
\hline $\begin{array}{l}\text { PVE }+6 \% \\
\text { Mgd }+10 \% \mathrm{TCP}\end{array}$ & 55 & $621(48)$ & 137 & 58 & 17 & 1281 \\
\hline $\begin{array}{l}\text { PVE }+6 \% \\
\mathrm{Mgd}+15 \% \mathrm{TCP}\end{array}$ & 48 & $547(54)$ & 124 & 54 & 16 & 1409 \\
\hline $\begin{array}{l}\text { PVE }+6 \% \\
\text { Mgd }+20 \% \mathrm{TCP}\end{array}$ & 38 & $449(58)$ & 117 & 48 & 17 & 1487 \\
\hline $\begin{array}{l}\text { PVE }+6 \% \\
M g d+25 \% \mathrm{TCP}\end{array}$ & 41 & $562(53)$ & 126 & 48 & 19 & 1343 \\
\hline $\begin{array}{l}\text { PVE }+6 \% \\
\mathrm{Mgd}+30 \% \mathrm{TCP}\end{array}$ & 39 & $444(63)$ & 111 & 42 & 17 & 1575 \\
\hline PVE + 6\% DPVPP & 67 & $752(37)$ & 89 & 67 & 15 & 1171 \\
\hline
\end{tabular}




\begin{tabular}{|l|l|l|l|l|l|l|}
\hline PVE + 6\% COPS $3 \mathrm{~h}$ & 67 & $979(18)$ & 107 & 85 & 20 & 931 \\
\hline
\end{tabular}

$t_{\text {ign }}$, Time to ignition; PHRR, peak heat release rate; $t_{\text {PHRR }}$, time to PHRR; THR, total heat released; AMLR, average mass loss rate; ASEA, average specific extinction area (smoke).

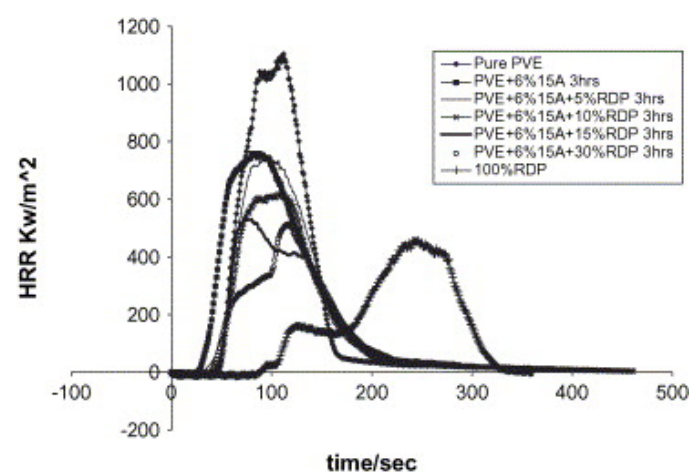

Fig. 20. Heat release rate curves for PVE + Cloisite $15 \mathrm{~A}+\mathrm{RDP}$ at $3 \mathrm{~h}$ mixing time.

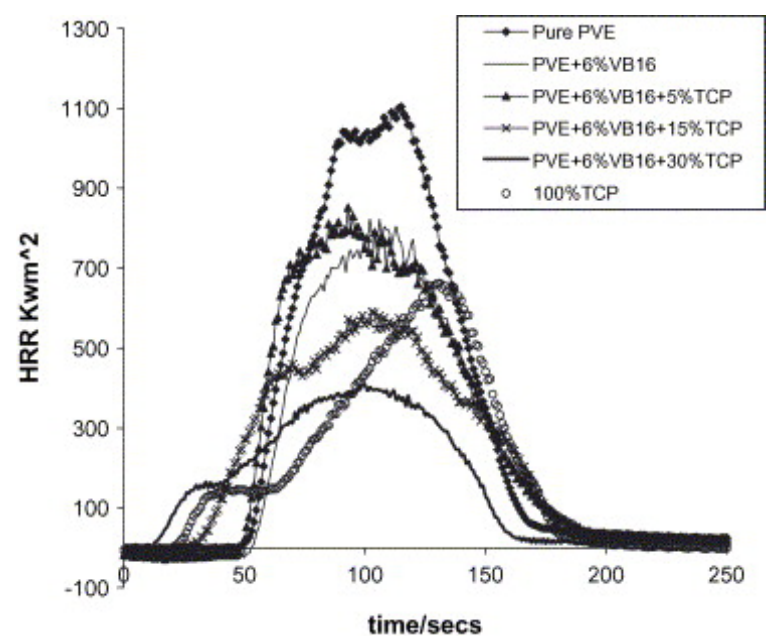

Fig. 21. Heat release rate curves for PVE + VB16-modified MMT + TCP at $3 \mathrm{~h}$ mixing time.

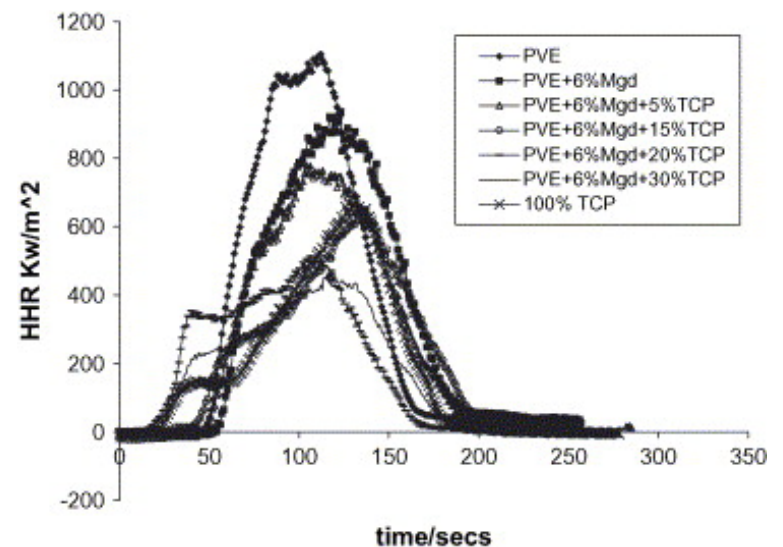

Fig. 22. Cone data for PVE + Magadiite modified + TCP at $3 \mathrm{~h}$ mixing time.

Magadiite (Mgd) and montomorillonite (MMT) clays have been compared with the same organic modifiers and the results are shown in Table 7. There is a clear difference in reduction in PHRR with MMT giving a good reduction while there is little change with Mgd. This agrees with previous work from this laboratory ${ }^{19}$ on Mgd modified polystyrene which shows minimal changes in PHRR while MMT shows 
more than $50 \%$ reduction. When the phosphate is added, both clays show about the same cone properties. The clay that may be chosen for some synergistic combination does not necessarily depend upon its fire retardant action when used alone but it is the total package, including effects on mechanical properties (to be discussed later in this paper) that must be considered.

Table 8 shows the result for the nanocomposites prepared by curing at different temperatures. At $30 \%$ $\mathrm{TCP}$, the reduction in PHRR is the same at $0{ }^{\circ} \mathrm{C}$ and room temperature. At lower amounts of phosphate, the curing temperature does affect the cone properties, in accord with what was seen by TEM.

Table 8. Cone calorimetric data for PVE systems cured at different temperatures

\begin{tabular}{|c|c|c|c|c|c|c|}
\hline Compound & $t_{\text {ign }}(s)$ & $\begin{array}{l}\text { PHRR }\left(\mathrm{kW} / \mathrm{m}^{2}\right)(\% \\
\text { reduction) }\end{array}$ & $t_{\mathrm{PHRR}}(\mathbf{s})$ & $\begin{array}{l}\text { THR } \\
\left(\mathrm{MJ} / \mathrm{m}^{2}\right)\end{array}$ & $\begin{array}{l}\text { AMLR } \\
\left(\mathrm{g} / \mathrm{stm}^{2}\right)\end{array}$ & $\begin{array}{l}\text { ASEA } \\
\left(\mathrm{m}^{2} / \mathrm{kg}\right)\end{array}$ \\
\hline Pure PVE & 82 & 1197 & 106 & 80 & 27 & 1015 \\
\hline $100 \%$ TCP & 25 & 663 & 132 & 51 & 29 & 1808 \\
\hline $100 \%$ RDP & 96 & 415 & 260 & 55 & 17 & 1641 \\
\hline PVE nano $0{ }^{\circ} \mathrm{C}$ & 77 & $631(47)$ & 183 & 76 & 16 & 1150 \\
\hline $\begin{array}{l}\text { PVE nano + 5\% TCP } \\
0{ }^{\circ} \mathrm{C}\end{array}$ & 72 & $546(54)$ & 143 & 72 & 15 & 1219 \\
\hline $\begin{array}{l}\text { PVE nano + 15\% TCP } \\
0{ }^{\circ} \mathrm{C}\end{array}$ & 56 & $462(61)$ & 139 & 60 & 16 & 1472 \\
\hline $\begin{array}{l}\text { PVE nano }+30 \% \mathrm{TCP} \\
0{ }^{\circ} \mathrm{C}\end{array}$ & 34 & $338(72)$ & 108 & 48 & 14 & 1660 \\
\hline PVE nano RT & 53 & $823(31)$ & 83 & 74 & 16 & 1033 \\
\hline $\begin{array}{l}\text { PVE + 6\% } 15 A+5 \% \\
\text { RDP RT }\end{array}$ & 68 & $856(32)$ & 93 & 69 & 17 & 931 \\
\hline $\begin{array}{l}\text { PVE nano + 15\% TCP } \\
\text { RT }\end{array}$ & 44 & $670(44)$ & 118 & 47 & 21 & 976 \\
\hline $\begin{array}{l}\text { PVE nano + 30\% TCP } \\
\text { RT }\end{array}$ & 29 & $299(75)$ & 105 & 38 & 13 & 1350 \\
\hline $\begin{array}{l}\mathrm{PVE}+\text { nano }+5 \% \mathrm{TCP} \\
90^{\circ} \mathrm{C}\end{array}$ & 30 & $428(64)$ & 83 & 52 & 14 & 1457 \\
\hline
\end{tabular}

$t_{\text {ign }}$, Time to ignition; PHRR, peak heat release rate; $t_{\text {PHRR }}$, time to PHRR; THR, total heat released; AMLR, average mass loss rate; ASEA, average specific extinction area (smoke).

Table 9 and Fig. 23 show the data for PVE-POSS nanocomposites prepared in both the presence and absence of phosphorous-containing material. From this data it is clear that there are significant reductions in PHRR for the nanocomposites and this reduction is further enhanced by the presence of a phosphorous-containing material. There is also a reduction in the total heat released of about $40-50 \%$ in the presence of both the phosphate and POSS, leading to reduced flammability for these systems. However, no reduction in the time to ignition was observed, as is typical of nanocomposites. The results obtained using POSS are quite similar to those using clays and these suggest that both are effective in producing enhanced fire retardancy.

Table 9. Cone calorimetric data for PVE-POSS nanocomposites

\begin{tabular}{|l|l|l|l|l|l|l|}
\hline Compound & $\boldsymbol{t}_{\text {ign }}$ & $\begin{array}{l}\text { PHRR }\left(\mathbf{k W} / \mathbf{m}^{2}\right) \mathbf{( \%} \\
\text { reduction) }\end{array}$ & $\boldsymbol{t}_{\text {PHRR }}(\mathbf{s})$ & $\begin{array}{l}\text { THR } \\
\left(\mathbf{M J} / \mathbf{m}^{2}\right)\end{array}$ & $\begin{array}{l}\text { AMLR } \\
\left(\mathbf{g} / \mathbf{s t m}^{\mathbf{2}}\right)\end{array}$ & $\begin{array}{l}\text { ASEA } \\
\left(\mathbf{m}^{\mathbf{2}} \mathbf{k g}\right)\end{array}$ \\
\hline Pure PVE & 82 & 1197 & 106 & 80 & 27 & 1015 \\
\hline
\end{tabular}




\begin{tabular}{|l|l|l|l|l|l|l|}
\hline $100 \%$ TCP & 25 & 663 & 132 & 51 & 29 & 1808 \\
\hline PVE + 5\% TCP & $75 \pm 4$ & $513 \pm 70(57)$ & $134 \pm 23$ & $47 \pm 2$ & $19 \pm 3$ & $1337 \pm 75$ \\
\hline PVE + 10\% TCP & $56 \pm 2$ & $459 \pm 120(62)$ & $151 \pm 10$ & $43 \pm 4$ & $19 \pm 2$ & $1572 \pm 38$ \\
\hline PVE + 3\% POSS & $71 \pm$ & $796(34)$ & 150 & 71 & 20 & 1027 \\
\hline PVE + 5\% POSS & $73 \pm$ & $844(29)$ & 128 & 62 & 19 & 1051 \\
\hline PVE + 10\% POSS & $69 \pm$ & $849(29)$ & 131 & 69 & 23 & 1104 \\
\hline $\begin{array}{l}\text { PVE + 4\% } \\
\text { POSS + 4\% TCP }\end{array}$ & $73 \pm 7$ & $436 \pm 45(64)$ & $136 \pm 3$ & $48 \pm 2$ & $17 \pm 2$ & $1307 \pm 33$ \\
\hline $\begin{array}{l}\text { PVE + 5\% } \\
\text { POSS + 10\% TCP }\end{array}$ & $64 \pm 9$ & $479 \pm 66(60)$ & $126 \pm 1$ & $39 \pm 3$ & $19 \pm 2$ & $1446 \pm 13$ \\
\hline $\begin{array}{l}\text { PVE + 5\% } \\
\text { POSS + 15\% TCP }\end{array}$ & $63 \pm 4$ & $483 \pm 15(60)$ & $149 \pm 1$ & $41 \pm 1$ & $20 \pm 0$ & $1468 \pm 38$ \\
\hline $\begin{array}{l}\text { PVE }+5 \% \\
\text { POSS + 30\% TCP }\end{array}$ & $36 \pm 1$ & $384 \pm 8(68)$ & $132 \pm 132$ & $32 \pm 2$ & $22 \pm 2$ & $1856 \pm 16$ \\
\hline
\end{tabular}

$t_{\text {ign }}$, Time to ignition; PHRR, peak heat release rate; $t_{\mathrm{PHRR}}$, time to PHRR; THR, total heat released; AMLR, average mass loss rate; ASEA, average specific extinction area (smoke).

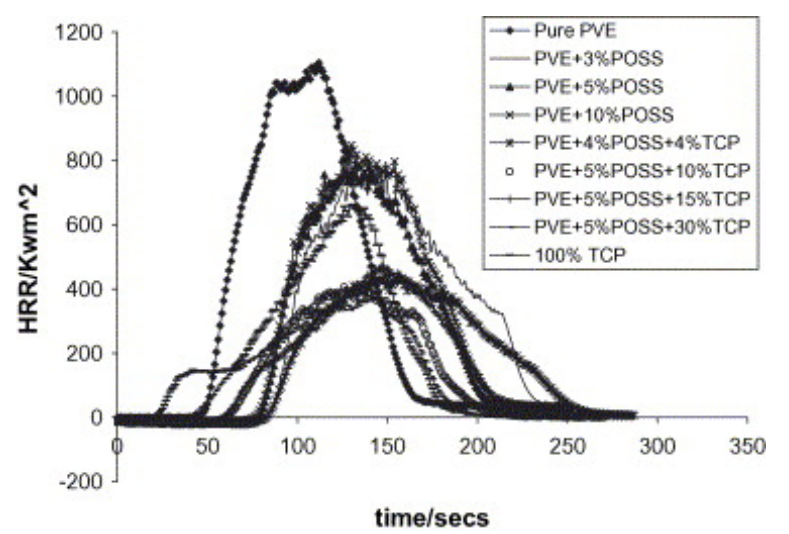

Fig. 23. Heat release rate curves for PVE-POSS + phosphate nanocomposites.

Fig. 24 and Table 10 show the cone data for the bromine-antimony (decabromodiphenyl oxide, $\mathrm{DBDPO} / \mathrm{Sb}_{2} \mathrm{O}_{3}$ ) containing PVE-clay nanocomposites. The time to ignition and time to PHRR are not changed while the total heat release and PHRR are reduced for the nanocomposites in the presence of the bromine-antimony combination. The reductions in flammability are proportional to the amount of antimony and bromine used. The best reduction in PHRR for this system was $72 \%$ and this is comparable to that obtained using 30\% TCP and 6\% 15A (75\%). Another significant observation is that the bromineantimony system gave a better reduction in PHRR than that observed for the brominated PVE resin. 


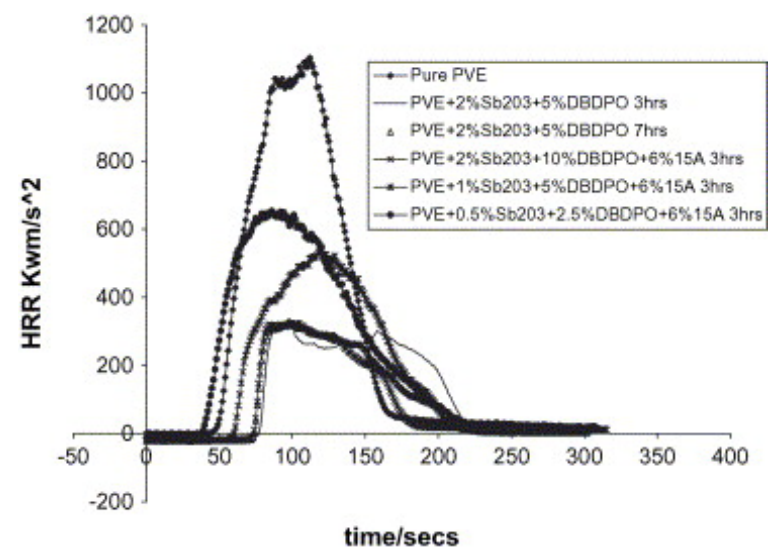

Fig. 24. Heat release rate curves for $\mathrm{PVE} / \mathrm{Sb}_{2} \mathrm{O}_{3} / \mathrm{DBDPO} /$ clay nanocomposites.

Table 10. Cone calorimetric data for PVE + decabrodiphenyl oxide (DBDPO)-antimony $\left(\mathrm{Sb}_{2} \mathrm{O}_{3}\right)$ nanocomposites

\begin{tabular}{|c|c|c|c|c|c|c|}
\hline Sample & $t_{\text {ign }}$ & $\begin{array}{l}\text { PHRR }\left(\mathrm{kW} / \mathrm{m}^{2}\right) \\
\text { (\% reduction) }\end{array}$ & $t_{\mathrm{PHRR}}(\mathrm{s})$ & $\begin{array}{l}\text { THR } \\
\left(\mathrm{MJ} / \mathrm{m}^{2}\right)\end{array}$ & $\begin{array}{l}\text { AMLR } \\
\left(\mathrm{g} / \mathrm{stm}^{2}\right)\end{array}$ & $\begin{array}{l}\text { ASEA } \\
\left(\mathrm{m}^{2} / \mathrm{kg}\right)\end{array}$ \\
\hline PVE & 82 & 1197 & 106 & & 27 & 1015 \\
\hline$+6 \% 15 \mathrm{~A}$ & 53 & $823(31)$ & 83 & 74 & 16 & 1033 \\
\hline $\begin{array}{l}+10 \% \text { DBDPO + } 2 \% \\
\mathrm{Sb}_{2} \mathrm{O}_{3} 3 \mathrm{~h}\end{array}$ & $89 \pm 14$ & $309 \pm 14(74)$ & $104 \pm 32$ & $33 \pm 2$ & $21 \pm 1$ & $2144 \pm 157$ \\
\hline $\begin{array}{l}+10 \% \text { DBDPO + } 2 \% \\
\mathrm{Sb}_{2} \mathrm{O}_{3} 7 \mathrm{~h}\end{array}$ & $100 \pm 2$ & $325 \pm 6(75)$ & $101 \pm 2$ & $28 \pm 1$ & $20 \pm 1$ & $3852 \pm 308$ \\
\hline $\begin{array}{l}+10 \% \text { DBDPO } 2 \% \\
\mathrm{Sb}_{2} \mathrm{O}_{3}+6 \% 15 \mathrm{~A}\end{array}$ & $93 \pm 10$ & $334 \pm 15(72)$ & $90 \pm 13$ & $29 \pm 3$ & $20 \pm 4$ & $1936 \pm 382$ \\
\hline $\begin{array}{l}+5 \% \text { DBDPO + 1\% } \\
\mathrm{Sb}_{2} \mathrm{O}_{3}+6 \% 15 \mathrm{~A}\end{array}$ & $76 \pm 8$ & $552 \pm 33(54)$ & $110 \pm 8$ & $46 \pm 2$ & $23 \pm 2$ & $1419 \pm 220$ \\
\hline $\begin{array}{l}+2.5 \% \text { DBDPO + 0.5\% } \\
\mathrm{Sb}_{2} \mathrm{O}_{3}+6 \% 15 \mathrm{~A}\end{array}$ & $75 \pm 13$ & $642 \pm 46(46)$ & $105 \pm 16$ & $66 \pm 1$ & $17 \pm 1$ & $1349 \pm 13$ \\
\hline Brominated resin & $89 \pm 41$ & $515 \pm 7(57)$ & $115 \pm 47$ & $42 \pm 1$ & $28 \pm 3$ & $1384 \pm 325$ \\
\hline
\end{tabular}

$t_{\text {ign, }}$, Time to ignition; PHRR, peak heat release rate; $t_{\mathrm{PHRR}}$, time to PHRR; THR, total heat released; AMLR, average mass loss rate; ASEA, average specific extinction area (smoke).

The cone calorimetric data for the glass fibre reinforced PVE nanocomposites in the presence and absence of putative fire retardants are shown in Table 11 while Fig. 25, Fig. 26 show the heat release rate and mass loss rate curves, respectively. From Fig. 25, it is clear that the phosphorous-containing samples do not exhibit as good a reduction in flammability as the brominated resin, which is used as the standard, or the non-brominated resin in which bromine is used as an additive. Thus for the glass fibre reinforced systems, the best choice appears to be either the brominated resin or the bromine-antimony system.

Table 11. Cone calorimetric data for PVE glass fibre reinforced nanocomposites

\begin{tabular}{|c|c|c|c|c|c|c|}
\hline Sample & $t_{\text {ign }}$ & $\begin{array}{l}\text { PHRR }\left(\mathrm{kW} / \mathrm{m}^{2}\right)(\% \\
\text { reduction) }\end{array}$ & $t_{\mathrm{PHRR}}(\mathbf{s})$ & $\begin{array}{l}\text { THR } \\
\left(\mathrm{MJ} / \mathrm{m}^{2}\right)\end{array}$ & $\begin{array}{l}\text { AMLR } \\
\left.\text { (g/stm }{ }^{2}\right)\end{array}$ & $\begin{array}{l}\text { ASEA } \\
\left(\mathrm{m}^{2} / \mathrm{kg}\right)\end{array}$ \\
\hline Virgin PVE & 85 & 276 & & 59 & & \\
\hline $\begin{array}{l}\text { Brominated PVE } \\
\text { (standard) }\end{array}$ & 77 & $141(49)$ & 199 & 27 & 12 & 1405 \\
\hline
\end{tabular}




\begin{tabular}{|l|l|l|l|l|l|l|}
\hline PVE + 6\% 15A + 15\% RDP & 78 & $258(7)$ & 200 & 55 & 9 & 1415 \\
\hline PVE + 6\% 15A + 30\% TCP & 80 & $197(30)$ & 205 & 43 & 9 & 1465 \\
\hline $\begin{array}{l}P V E+6 \% 15 A+10 \% \\
\text { DBDPO + 2\% } \mathrm{Sb}_{2} \mathrm{O}_{3}\end{array}$ & 79 & $167(39)$ & 223 & 36 & 8 & 1270 \\
\hline $\begin{array}{l}\mathrm{PVE}+10 \% \mathrm{DBDPO}+2 \% \\
\mathrm{Sb}_{2} \mathrm{O}_{3}\end{array}$ & 87 & $175(37)$ & 113 & 41 & 11 & 1443 \\
\hline
\end{tabular}

$t_{\text {ign, }}$, Time to ignition; PHRR, peak heat release rate; $t_{\mathrm{PHRR}}$, time to PHRR; THR, total heat released; AMLR, average mass loss rate; ASEA, average specific extinction area (smoke).

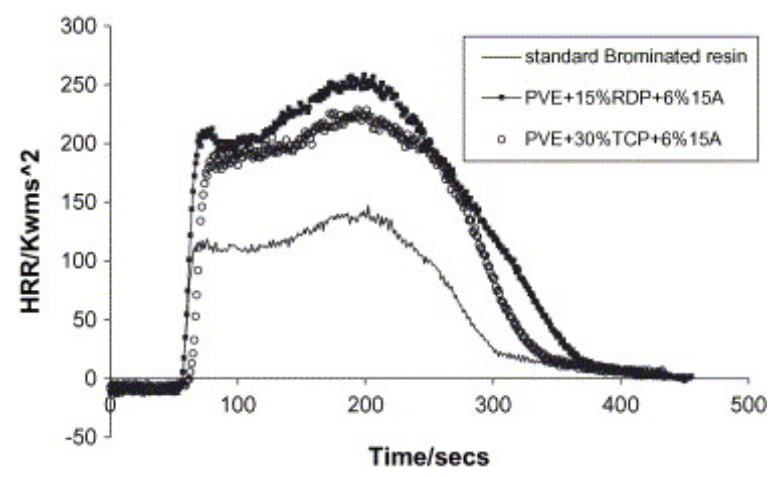

Fig. 25. Heat release rate curves for glass fibre reinforced samples.

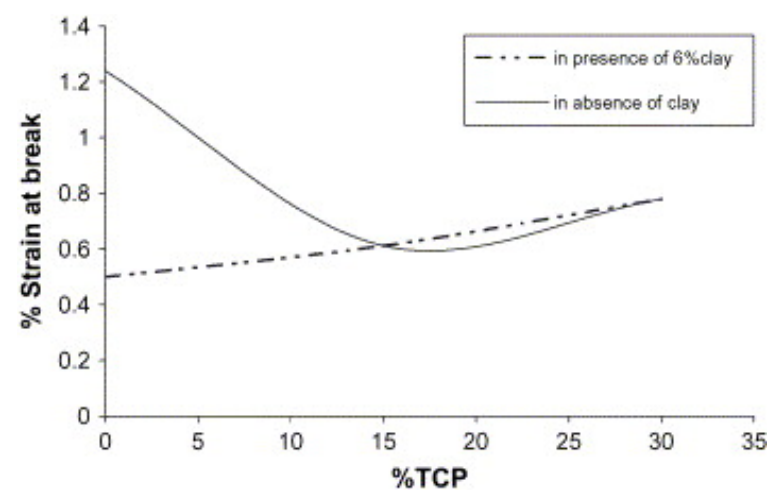

Fig. 26. Effect of TCP in presence and absence of clay on the strain at break.

\subsubsection{Evaluation of mechanical properties}

An effort to reduce flammability by the incorporation of additives, like phosphates, in the polymers and nanocomposites can have an adverse effect on the mechanical properties of the polymer. Table 12 , Table 13 show that the Young's modulus (stress/strain), a measure of the stiffness of the material at the start of a tensile test, is relatively unaffected by the presence of the phosphate up to $15 \%$ concentration in the nanocomposite-phosphate composition. As the amount of phosphate is increased up to $30 \%$ there is about a $50 \%$ reduction in Young's modulus. There is no difference in modulus as a function of mixing time, which confirms that the dispersion time has no effect on the properties of the nanocomposites formed from these epoxy vinyl ester resins. The peak stress at break, which is a measure of the ultimate strength that a material can bear before break, decreases with an increase in amount of phosphate. The decrease is more pronounced with TCP than with RDP, showing that the particular phosphate used can have an important effect on the mechanical properties of the materials. An increase in the fire retardant also decreases the peak load of the sample. The percent strain at break increases with an increase in the fire retardant composition, which must be due to the plasticising effect 
of the phosphorous-containing compounds. Fig. 26, Fig. 27 show that stress and strain are affected by the presence of phosphate.

Table 12. Mechanical properties for TCP PVE samples

\begin{tabular}{|l|l|l|l|l|}
\hline Specimen & $\begin{array}{l}\text { Peak load } \\
(\mathbf{k N})\end{array}$ & $\begin{array}{l}\text { Peak stress } \\
\text { (MPa) }\end{array}$ & $\begin{array}{l}\text { Strain at break } \\
(\mathbf{\%})\end{array}$ & $\begin{array}{l}\text { Modulus } \\
\text { (GPa) }\end{array}$ \\
\hline Pure PVE & 0.21 & 37.6 & 1.24 & 4.29 \\
\hline PVE + 6\% 15A 3 h & 0.17 & 18.65 & 0.5 & 4.45 \\
\hline PVE + 6\% 15A 30 min & 0.18 & 22.5 & 0.928 & 4.562 \\
\hline PVE + 15\% TCP 30 min & 0.252 & 27.1 & 1.012 & 4.732 \\
\hline PVE + 30\% TCP 30 min & 0.121 & 16.4 & 0.931 & 2.346 \\
\hline $\begin{array}{l}\text { PVE + 6\% 15A + 15\% TCP } \\
\text { 3 h }\end{array}$ & 0.133 & 19.3 & 0.612 & 3.686 \\
\hline $\begin{array}{l}\text { PVE + 6\% 15A + 30\% TCP } \\
\text { 3 h }\end{array}$ & 0.035 & 9.2 & 0.779 & 1.749 \\
\hline
\end{tabular}

Table 13. Mechanical properties for RDP PVE samples

\begin{tabular}{|l|l|l|l|l|}
\hline Specimen & $\begin{array}{l}\text { Peak load } \\
\text { (kN) }\end{array}$ & $\begin{array}{l}\text { Peak stress } \\
\text { (MPa) }\end{array}$ & $\begin{array}{l}\text { Strain at break } \\
\text { (\%) }\end{array}$ & $\begin{array}{l}\text { Modulus } \\
\text { (GPa) }\end{array}$ \\
\hline Pure PVE & 0.21 & 37.6 & 1.24 & 4.29 \\
\hline PVE + 6\% 15A 3 h & 0.17 & 18.65 & 0.5 & 4.45 \\
\hline PVE + 6\% 15A 30 min & 0.18 & 22.5 & 0.928 & 4.562 \\
\hline $\begin{array}{l}\text { PVE + 6\% 15A + 15\% RDP } \\
\text { 3 h }\end{array}$ & 0.141 & 20.1 & 0.628 & 4.098 \\
\hline $\begin{array}{l}\text { PVE + 6\% 15A + 30\% RDP } \\
\text { 3 h }\end{array}$ & 0.139 & 17.9 & 1.112 & 2.526 \\
\hline
\end{tabular}

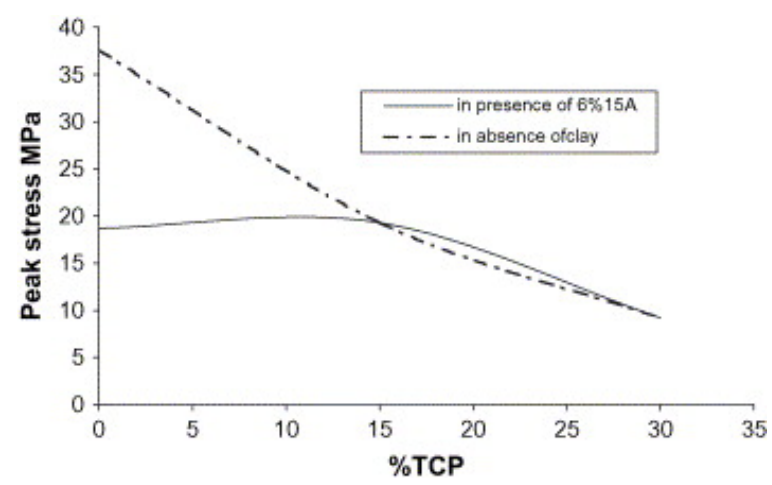

Fig. 27. Effect of TCP in presence and absence of clay on the peak stress.

\section{Conclusions}

In this study synergy between conventional phosphorous-containing fire retardants and vinyl ester nanocomposites is shown through cone calorimetry by reductions in the peak heat release rate, total heat release and mass loss rate; there is no improvement in the time to ignition. These reductions were directly proportional to the amount of phosphate added. With both resins the type of clay used showed different effects on the flammability of the nanocomposites formed but there was no effect from the 
atmosphere in which the nanocomposite was formed. The cone calorimetric parameters are comparable to the brominated resin when the systems are not glass reinforced but this brominated resin gives better performance when glass reinforcement is used.

\section{Acknowledgment}

This work has been performed under the sponsorship of the Office of Naval Research under grant number N00014-03-1-0172 and their support is gratefully acknowledged.

\section{References}

1 Russell BP, Giuseppe PR. J Appl Polym Sci 2000;76:1572.

2 Tucker R, Compston P, Jar P-YB. Compos Appl Sci Manuf Part A 2001;32:129.

3 Abadie MJM, Kekhissi K, Burchill PJ. J Appl Polym Sci 2002;84:1146.

4 Ziaee S, Palmese GR. Appl Polym Sci Part B Polym Phys 1999;37:725.

5 Wang MS, Pinnavia TJ. Chem Mater 1994;6:468.

6 Yang H, James Lee L. Polym Compos 2001;22(5):668.

7 Dua S, McCullough RL, Palmese GR. Polym Compos 1999;20(3):379.

8 Gilman JW, Kashiwagi T, Nyden M, Brown JET, Jackson S, Lomakin S, et al. In: Al-Malaiki S, Golovoy A, Wilkie CA, editors. Chemistry and technology of polymer additives. BlackWell Scientific; 1999. p. $249 \mathrm{e} 65$.

9 Esker AR, Vastine BA, Deng J, Polidan JT, Viers BD, Satiji SK. Abstracts of papers, 225th ACS National meeting, New Orleans, LA; 2003, March 23e27.

10 Xu H, Kuo S-W, Huang C-F. J Polym Res 2002;9(4):239e44.

11 Li G, Wang L, Ni H, Pittman Jr CU. J Inorg Organmet Chem 2002;11:123.

12 Troitzsch J. International plastics flammability handbook. 2nd ed. Hanser Publishers; 1990. p. 46.

13 Larsen ER. Halogenated flame retardancy. In: Kirk Othmer encyclopedia of chemical technology, vol. 10. John Wiley; 1980. p. 382.

[14] Zheng X, Wilkie CA. Polym Degrad Stab 2003;81:539e50.

[15] Chigwada G, Wilkie CA. Polym Degrad Stab 2003;80:551e7.

[16] Weil ED. Flame retardants of phosphorous compounds. In: Kirk Othmer encyclopedia of chemical technology, vol. 10. 1980. p. 382.

[17] Su S, Jiang DD, Wilkie CA. Polym Degrad Stab 2004;83: 333e46.

[18] Bourbigot S, Vanderhart DL, Gilman JW, Awad WH, Davis RD, Morgan AB, et al. J Polym Sci Part B Polym Phys 2003;41:3188e213.

[19] Wang D, Jiang DD, Pabst J, Han Z, Wang J, Wilkie CA. Polym Eng Sci 2004;44:1122e31.

[20] Zhu J, Morgan AB, Lamelas FJ, Wilkie CA. Chem Mater 2001;13:3774e80.

[21] Blumstein A. Polymerization of adsorbed monolayers. 1. Preparation of the clayepolymer complex. J Polym Sci Part A 1965;3(7):2653e64. 